\title{
Role of Carbonic Anhydrase and Triiodothyronine in Dental Caries Affected Children in Fluorosis Endemic Areas
}

\author{
Arjun L Khandare ${ }^{1 *}$, Vakdevi Validandi ${ }^{1}$, Gopalan Viswanathan ${ }^{1}$, G Shankar Rao ${ }^{1}$ and N Balakrishna ${ }^{2}$ \\ ${ }^{1}$ Department of Food Toxicology, National Institute of Nutrition \& Indian Council of Medical Research, India \\ ${ }^{2}$ Department of Statistics, National Institute of Nutrition \& Indian Council of Medical Research, India
}

Submission: January 30, 2018; Published: February 19, 2018

*Corresponding author: Arjun L Khandare, Scientist 'F' (Deputy Director, Sr. Grade), Head Department of Food Toxicology, National Institute of Nutrition, Indian Council of Medical Research, Jamai-Osmania PO, Hyderabad - 500007, Telangana, India, Tel: +919160040377,

Email: alkhandare@yahoo.com

\begin{abstract}
Caries being a public health problem, drinking water has been fluoridated since 1942 in 25 countries to prevent it. About 745 boys and 813 girls are recruited from endemic villages of Nalgonda district, Telangana and were categorised into three strata based on their fluoride levels in drinking water as Category I (0.83ppm), Category II (2.08ppm) and Category III (2.82ppm). Prevalence of dental fluorosis and caries were examined. Blood and urine samples were collected from children of the respective areas. Significantly high prevalence of dental fluorosis was found in category III ( $81 \%$ to $84 \%$ ) when compared with category I ( $12 \%$ to $29 \%$ ) and II ( $22 \%$ to $58 \%$ ). Carbonic anhydrase activity was significantly reduced $(\mathrm{p}<0.05)$ in category III than category I and II. T3 level was significantly decreased in category II as compared to category I. There was a reduction in carbonic anhydrase and T3 in high fluoride areas. However, there was no significant difference in dental caries among the study population in high fluoride areas.
\end{abstract}

Keywords: Carbonic anhydrase; Dental caries; Fluoride; Dental fluorosis; Nutrition status; Triiodothyronine

\section{Introduction}

Dental caries is the localized degradation of susceptible dental hard tissues by acidic by-products from bacterial fermentation of dilatory carbohydrates [1]. Dental caries is a public health problem; it affects a large number of populations around the world. National health survey and fluoride mapping in India [2] found the prevalence of dental caries among 12-15 year old children was $38 \%$ and $63.1 \%$ respectively. Literature review revealed that the relation between fluoride concentrations in drinking water with dental caries is in conflicting. Few earlier studies reported an inverse relation $[3,4]$ while others found no relation [5] or a positive association [6,7]. Fluoride therapy has been the main caries preventive strategy since the introduction of water fluoridation schemes several decades ago [8]. In spite of the use of fluoride containing tooth pastes and mouth rinses in US, still $60 \%$ teenagers are suffering from different forms of dental caries. Hence, the anti-caries effect of traditional fluoride therapy is still limited [9].
Moreover, the usage of fluoride containing tooth pastes and mouth rinses are not sufficient for minimizing the formation of caries as they are unable to maintain the required fluoride concentration $[10,11]$. In order to achieve the effective fluoride concentration, it is required to expose 4-5ppm F. By exposure of required $\mathrm{F}$ concentration May leads to dental and skeletal fluorosis including inhibition of Carbonic Anhydrase (CA) which plays major role in acid base balance intern affects $\mathrm{F}$ excretion and caries formation. It is also known that iodine plays an important role in caries formation and $\mathrm{F}$ create secondary iodine deficiency in fluorotic areas. Under this situation it is important to know the dental caries prevalence in fluorotic area. Hence, the present study has been undertaken with an aim to know the caries prevalence, carbonic anhydrase activity and T3 levels in the fluorotic area. It is reported that the salivary carbonic anhydrase activity is decreased in dental caries. However, no studies have been reported on the CA activity on caries in fluorotic area. Hence, the study was carried 
out to know the status of CA activity and its relations with dental caries and to design the intervention strategies.

\section{Materials and Methods}

\section{Study design}

This was the cross sectional study conducted by recruiting 1558 (about 500-550 school children were recruited in each category school) children aged 8-14 year were included in this study for clinical examination. The study was completed during March and April 2015. The schools were divided into 3 strata based on mean fluoride level in drinking water $0.83 \mathrm{ppm}$ (Category I), 2.08ppm (Category II), 2.82ppm (Category III). The selected schools were listed and permission to conduct the study in these schools was obtained from District Collector, Nalgonda and concerned school Headmasters. The programme for conducting the survey among these school children was prepared well in advance and sent to the concerned Headmasters. The survey was conducted in all the children age from 8 to 14 years. The children who were not resident of that village and age below 8 years and above 14 years were excluded from the study. Ethical clearance for the study was obtained from the Institutional Human Ethical Committee (IEC No 15/II/2014). An initial training and calibration exercise was conducted to provide practical experience in the study methodology and coding for the dental examiner through expert prior to the survey. The clinical examination was carried out in a school under natural day light on the ordinary chair. Subjects were made to sit in the chair in on upright position using wall as the headrest.

\section{Assessment of dental caries}

Dental caries was assessed using texture status. The DMFT (decayed, missed and filled teeth) level of an individual was calculated by number of decayed, missed and filled teeth except wisdom teeth and exclusion of dematerialized (white spot) lesions. Then the total DMFT in an area was assessed by dividing the sum of DMFT of affected children in the respective area with total number of children examined as per the following formula.

\section{Assessment of dental fluorosis}

According to the Deans classification, prevalence of fluorosis was assessed in each category of villages [12]. The percentage incidence of fluorosis was calculated from the number of people affected by fluorosis in the respective category with total number of people surveyed.

\section{Nutrition status (Anthropometric measurements)}

Anthropometric measurements (height and weight) were used to assess nutritional status of the subjects. Height was measured using a standard calibrated rod to the nearest $1 \mathrm{~mm}$ (Model seca 216, UK) and weight was measured to the nearest $10 \mathrm{~g}$ with a standard calibrated digital balance (Model secaclara 803, UK). Age of the children was calculated from their date of birth. All the measurements were carried out based on the recommended standard methods by trained technician and compared with WHO reference [13].

\section{Collection of water, urine and blood samples}

Water samples from all the drinking water sources were collected in the high density polyethylene bottles. Spot urine samples were collected in the plastic bottles and 2-3 drops of toluene was added to avoid microbial growth. Then the water and urine samples were transferred to laboratory at National Institute of Nutrition and stored at $4^{\circ} \mathrm{C}$ till further use. During the school visit for clinical examination about $5 \mathrm{ml}$ blood was collected from randomly selected $20 \%$ students, and transported to NIN laboratory under cold condition using vaccine carrier. Blood samples were centrifuged at $4^{\circ} \mathrm{C}$ to collect the plasma/serum and RBCs separated immediately frozen at $-80^{\circ} \mathrm{C}$ till further use.

\section{Analysis of Fluoride in water and urine}

Fluoride in water and urine was analyzed using ion Selective electrode, Orion 9609 [14].

\section{Estimation of T3 level in serum}

T3 level in serum samples was analysed by using DiaSorin kits supplied by DiaSorin Minnesota, USA.

\section{Carbonic Anhydrase (CA) assay}

RBC was haemolysed in cold distilled water and centrifuged at $10,000 \mathrm{rpm}$ maintaining $4^{\circ} \mathrm{C}$ for $15 \mathrm{~min}$. The clear haemolysate was assayed for CA activity by the Electrometric method of Wilbur and Anderson, 1948 [15]. The enzyme activity was expressed as Units /gHb.

\section{Results}

We studied 1558 children [745 (48\%)Boys and 813 (52\%) Girls] in nine villages from 4 blocks of Nalgonda district (Figure 1). The selected villages were categorized into three categories based on drinking water fluoride levels. A total of 1558 (about 500-550 school children were recruited in each category school) children aged 8-14 year were included in this study for clinical examination. Based on fluoride level in their drinking water, all the villages were categorised in to three categories (Table 1). Drinking water fluoride levels in categories II and III was significantly higher ( $F=64.87, p<0.001$ ), when compared with category I (control villages). Mean water and urinary fluoride along with BMI of children of different age groups in different category villages are given in Table 1.

The prevalence of dental fluorosis (DF) was found highest (81-84\%) in category III among all the age groups. Whereas, in category II DF was lower (22-58\%), where as in the age group of 14 years children were most affected than other age groups. Even though the drinking water fluoride was comparable to permissible limit in category I villages the prevalence of dental fluorosis was ranging from $16 \%$ to $29 \%$ among all the age groups (Table 1). There was no sex bias was found in dental fluorosis in 


\section{Advances in Dentistry \& Oral Health}

the entire categories. There was no significant difference in dental caries among all the categories ranging from $57 \%$ to $63 \%$. Figure 2 shows normal teeth and dental caries along with and without
DF. The caries corresponding DMFT was also showed the similar trend among three categories of children (Table 2).

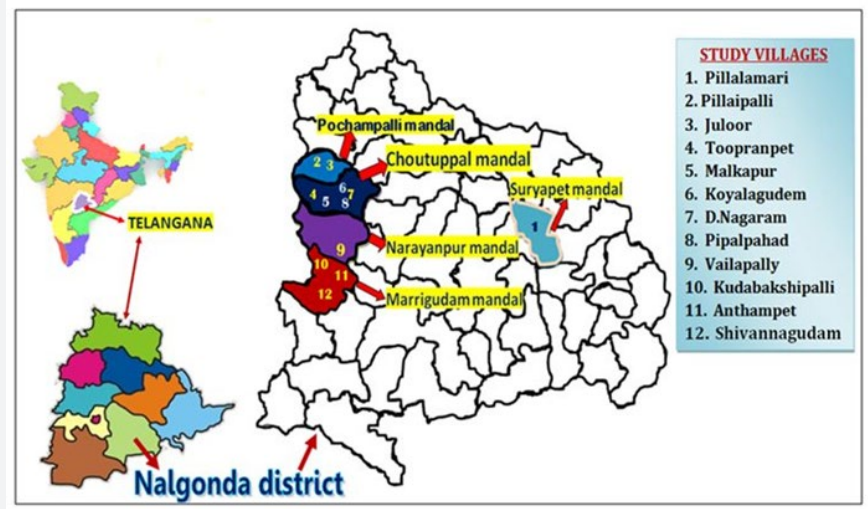

Figure 1: Study areas in Nalgonda district, Telangana, India.

Table 1: Fluoride level in drinking water and urine, prevalence of fluorosis and the BMI of children (8-14 years) in study areas of Nalgonda district.

\begin{tabular}{|c|c|c|c|c|c|c|}
\hline \multirow[b]{2}{*}{ Area Category } & \multirow{2}{*}{$\begin{array}{l}\text { Water Fluoride Level } \\
(\mathrm{mg} / \mathrm{L})(\text { Mean } \pm \text { SD) }\end{array}$} & \multirow{2}{*}{$\begin{array}{l}\text { Urinary Fluoride } \\
\text { Level }(\mathrm{mg} / \mathrm{L}) \\
\text { (Mean } \pm \text { SD) }\end{array}$} & \multicolumn{3}{|c|}{ Prevalence of Fluorosis } & \multirow{2}{*}{$\begin{array}{c}\text { BMI }\left(\mathrm{kg} / \mathrm{m}^{2}\right) \\
\pm \mathrm{SD})\end{array}$} \\
\hline & & & 8-10 years $N(\%)$ & $\begin{array}{l}\text { 11-13 years } \\
\mathrm{N}(\%)\end{array}$ & $\begin{array}{l}14 \text { years } \mathrm{N} \\
(\%)\end{array}$ & \\
\hline $\mathrm{I}(\mathrm{N}=506)$ & $0.83 \pm 0.28$ & $1.58 \pm 0.92$ & $59(28.8)$ & $262(16)$ & $185(11.9)$ & $16.1 \pm 2.33$ \\
\hline II $(\mathrm{N}=504)$ & $2.08^{*} \pm 1.34$ & $1.90 * \pm 1.18$ & $98(22.4)$ & $196(46.6)$ & $210(58.1)$ & $16.0 \pm 2.70$ \\
\hline III $(\mathrm{N}=548)$ & $2.82^{*} \pm 0.97$ & $3.38 * \pm 2.09$ & $129(81.8)$ & $226(81)$ & $193(83.9)$ & $15.8^{*} \pm 2.39$ \\
\hline
\end{tabular}

${ }^{*} \mathrm{p}<0.05$ with area of category I.

Table 2: Prevalence of dental caries N (\%) among different age groups of boys and girls and total DMFT Different age groups in study areas of different categories.

\begin{tabular}{|c|c|c|c|c|c|c|c|c|c|c|}
\hline \multirow{2}{*}{ Area Category } & \multicolumn{2}{|c|}{ 08-10 year $N(\%)$} & \multicolumn{2}{|c|}{$11-13$ year $\mathrm{N}(\%)$} & \multicolumn{2}{|c|}{14 year $N(\%)$} & \multirow{2}{*}{$\begin{array}{c}\text { Total N } \\
\text { (\%) }\end{array}$} & \multicolumn{3}{|c|}{ Total DMFT Levels } \\
\hline & Boys & Girls & Boys & Girls & Boys & Girls & & 8-10 years & 11-13 years & 14 year \\
\hline $\mathrm{I}(\mathrm{N}=506)$ & $16(64)$ & $18(53)$ & $80(64)$ & $77(56)$ & $45(54)$ & $53(52)$ & $289(57)$ & 1.235 & 1.221 & 1.21 \\
\hline II $(N=504)$ & $28(55)$ & $33(67)$ & $60(62)$ & $55(56)$ & $65(58)$ & $62(65)$ & $303(60)$ & 1.186 & 1.207 & 1.226 \\
\hline III $(\mathrm{N}=548)$ & $46(89)$ & $48(63)$ & $58(57)$ & $71(55)$ & $57(63)$ & $58(59)$ & $339(62)$ & 1.2 & 1.163 & 1.77 \\
\hline
\end{tabular}

\begin{tabular}{|c|c|c|c|}
\hline & \\
Dental caries with fluorosis & Dental caries with fluorosis \\
Dental caries with fluorosis
\end{tabular}

Figure 2: Appearance of normal, dental fluorosis, dental caries and dental fluorosis with dental caries teeth of children in study areas of Nalgonda district. 


\section{Advances in Dentistry \& Oral Health}

Carbonic anhydrase activity was assessed in RBC which was significantly reduced $(\mathrm{P}<0.05)$ in category III as compared to category I and II whereas Triiodothyronine (T3) was significantly decrease $(\mathrm{P}<0.05)$ in category II compared to category I (Table 3 ). Relation between dental fluorosis, dental caries, BMI, CA activity and T3 levels are given in the Table 4. It has been revealed that, positive correlation was found between dental caries with dental fluorosis. However, other correlations in respect to caries with CA activity, BMI and T3 had negative correlation.

Table 3: Prevalence of dental fluorosis, dental caries, carbonic anhydrase activity, triiodothyronine (T3) levels in children of various categories of study areas in Nalgonda district.

\begin{tabular}{|c|c|c|c|c|}
\hline Area Category & $\begin{array}{c}\text { Prevalence of Dental } \\
\text { Fluorosis (\%) }\end{array}$ & $\begin{array}{c}\text { Prevalence of Dental } \\
\text { Caries (\%) }\end{array}$ & $\begin{array}{c}\text { Carbonic Anhydrases } \\
\text { Activity (U/gHb) } \\
\text { (Mean } \pm \text { SD) }\end{array}$ & $\begin{array}{c}\text { Triiodothyronine (T3) } \\
\text { Level (ng/mL) } \\
\text { (Mean } \pm \text { SD) }\end{array}$ \\
\hline I & 16 & 57 & $25.08 \pm 2.36$ & $1.95 \pm 0.64$ \\
\hline II & $47^{*}$ & 60 & $23.38 \pm 4.37$ & $1.47^{*} \pm 0.59$ \\
\hline III & $82^{*}$ & 62 & $14.17^{*} \pm 2.53$ & $1.64 \pm 0.59$ \\
\hline
\end{tabular}

${ }^{*} p<0.05$

Table 4: Relationships between dental fluorosis, dental caries, BMI, carbonic anhydrases and (T3) level in study areas (Category I to III).

\begin{tabular}{|c|c|c|c|c|c|}
\hline & Regression Equation & $\mathbf{r}$ & $\mathbf{r}^{2}$ & $\mathbf{p}$ & $\begin{array}{l}\text { One way ANOVA } \\
\text { (F - value) }\end{array}$ \\
\hline \multicolumn{6}{|c|}{ Dental Caries (X) Vs } \\
\hline Dental fluorosis $(\mathrm{Y})$ & $Y=12.97 X-726$ & 0.9888 & 0.9777 & 0.0954 & 0.35 \\
\hline $\begin{array}{c}\text { Carbonic } \\
\text { anhydrases (Y) }\end{array}$ & $Y=-2.05 X+143$ & -0.8808 & 0.7758 & 0.314 & 111 \\
\hline BMI (Y) & $Y=-0.058 X+19.42$ & -0.9538 & 0.9097 & 0.1942 & 901 \\
\hline T3 (Y) & $Y=-0.07 X+5.85$ & -0.7211 & 0.5199 & 0.4873 & 1577 \\
\hline \multicolumn{6}{|c|}{ Dental Fluorosis (X) Vs } \\
\hline $\begin{array}{c}\text { Carbonic } \\
\text { anhydrases (Y) }\end{array}$ & $Y=-0.167 X+28.97$ & -0.9417 & 0.8867 & 0.2185 & 2 \\
\hline BMI (Y) & $Y=-0.014 X+16.43$ & -0.926 & 0.8574 & 0.2464 & 2.9 \\
\hline T3 (Y) & $Y=-0.0045 X+1.904$ & -0.6095 & 0.3714 & 0.5827 & 6 \\
\hline
\end{tabular}

$P<0.05$ considered as statistically significant.

\section{Discussion}

In the present study particularly in category II, III severity of fluorosis has been increased due to the exposure of excess fluoride in their drinking water however there was no difference in dental caries prevalence. Disorders in acid-base balance affect the renal handling of fluoride such that, in acidosis, the excretion rate is diminished and, in alkalosis, the excretion rate is enhanced. Congenital persistent proximal type renal tubular acidosis causes enamel defects, enamel hypoplasia and peg-shaped teeth [16]. Thus, any factor that can decrease urinary $\mathrm{pH}$ would be expected to increase the likelihood of dental fluorosis and vice versa [16]. The changes in acid-base balance have effect on dentine metabolism similar to the bone. In the present study, at higher level of fluoride decreased CA activity, which leads to acidosis, decrease of $\mathrm{pH}$ cause demineralization and hypoplasia leads to caries. Bäckman et al. [16] found that chronic metabolic acidosis slowed lowers the rate of dentine formation and the general body growth in the young rats. The odontoblasts are partly same metabolic regulation as the osteoblasts, hence the formation of the bone and the dentine are probably regulated by similar factors. Low salivary CA VI is associated with the increase of caries prevalence and a negative correlation between CA VI and DMFT index in individuals has been reported by Kivela et al. [17].

There are many studies all over the globe on dental caries and dental fluorosis [18] since 1942 important milestone discovery by Dean et al. [12] states that, 1ppm of $\mathrm{F}$ in drinking water has maximum reduction of caries and very mild dental fluorosis [12]. After this, community water fluoridation was initiated in the USA in 1945 and is currently practiced in about 25 countries around the world. However, they experience more risk than benefits of fluoridation of drinking water. It is believed that a minimum serum fluoride level of $0.1 \mu \mathrm{g} / \mathrm{ml}(0.1 \mathrm{ppm})$ must be achieved before odentoblasts will be stimulated and remineralisation takes place at decayed tooth. We found in the present study there was no significant difference in caries irrespective of $\mathrm{F}$ in drinking water which agrees earlier report [5]. There are few studies where they correlate caries with nutritional status (BMI), however, in some studies where BMI was not statistically associated with DMFT, in our study we conclude, within the limits of a cross-sectional survey, that there is a negative association between these two variables, which agrees with the earlier study [19] (Table 4). In the present study we have assessed the CA activity in RBC to know 
the effect of CA on caries, we found significant inhibition of CA in category II, and III which indicate acidification effect, contribute decrease the salivary pH. Salivary carbonic an hydrase (CA VI) is the secreted iso-enzyme of the CA family. There is evidence to suggest that salivary CA is a multifunctional enzyme, which affects taste bud growth, protecting the teeth from caries and act as an anti-inflammatory agent $[4,5]$.

Low salivary CA VI concentration is associated with the increased prevalence of caries, and a negative correlation between CA VI concentration and DMFT index in individuals has been reported by Kivela et al. [17]. Hence in the present study also showed lower levels of CA because of high F may be the reason of high prevalence of caries in category II and III school children. Significant reduction in T3 level from normal area to high fluoride area indicates that the children in fluorosis endemic areas were receiving less iodine. However, the administration of iodine gives resistance to caries, retarding the process and reducing its resistance. Iodine and fluorine do have mutually interacting effects on both goitre and fluorosis in the experimental mice [20]. Some more epidemiological studies required to confirm the results.

\section{Conclusion}

There was a reduction in CA activity and T3 levels in high fluoride areas, it reveals that CA activity and T3 levels could not show significant effect on caries formation in high fluoride areas.

\section{Acknowledgements}

The authors acknowledge the encouragement and guidance of Director-Incharge, National Institute of Nutrition, ICMR, India. The authors thank the UNICEF for financial assistance to conduct the study.

\section{References}

1. Marsh P, Martin MV (1999) Oral Microbiology. ( $4^{\text {th }}$ edn) Wright; Oxford.

2. World Health Organization. (1990) Educational Imperatives for Oral Health Personnel: Change or Decay? WHO, Geneva, Switzerland.

3. Shekar C, Cheluvaiah MB, Namile D (2012) Prevalence of dental caries and dental fluorosis among 12 and 15 years old school children in relation to fluoride concentration in drinking water in an endemic fluoride belt of Andhra Pradesh. Indian J Public Health 56(2): 122128.

4. Fejerskov O, Larsen MJ, Richards A, Baelum V (1994) Dental tissue effects of fluoride. Adv Dent Res 8(1): 1531.

5. Horowitz HS, Heifetz SB, Meyers RJ, Driscoll WS, Korts DC (1977) Evaluation of a combination of selfadministered fluoride procedures for control of dental caries in a nonfluoride area: Findings after 2 years. Caries Res 11(3): 178185.

6. Grobler SR, van Wyk CW, Kotze D (1986) Relationship between enamel fluoride levels, degree of fluorosis and caries experience in communities with a nearly optimal and a high fluoride level in the drinking water. Caries Res 20(3): 284288.

7. Grobleri SR, Louw AJ, van Kotze TJ (2001) Dental fluorosis and caries experience in relation to three different drinking water fluoride levels in South Africa. Int J Paediatr Dent 11(5): 372379.

8. Olsson B (1979) Dental findings in highfluoride areas in Ethiopia. Community Dent Oral Epidemiol 7(1): 5156.

9. Featherstone JD (2009) Remineralization, the natural caries repair process-the need for new approaches. Adv Dent Res 21(1): 4-7.

10. Leverett DH, Featherstone JD, Proskin HM (1993) Caries risk assessment by a cross-sectional discrimination model. J Dent Res 72(2): 529-537.

11. Eakle WS, Featherstone JD, Weintraub JA, Shain SG, Gansky SA (2004) Salivary fluoride levels following application of fluoride varnish or fluoride rinse. Community Dent Oral Epidemiol 32(6): 462-469.

12. Dean HT (1942) The investigation of physiological effects by the epidemiological method. In: Moulton, RF (Ed.), Fluorine and Dental Health. American Association for Advancement of Science, Washington DC, USA, p. 23-31.

13. Lohman TJ, Roache AF, Martorell R (1992) Anthropometric standardization reference Manual, Champaign, IL: Human Kinetics Books, USA

14. Tusl J (1970) Direct determination of fluoride in human urine using fluoride electrode. J Clin Chem Acta 27(1): 216-218.

15. Wilbur KM, Anderson NG (1948) Electrometric and colorimetric determination of carbonic anhydrase. J Biol Chem 176(1): 147-154.

16. Backman T (1999) Acid-base balance, dentinogenesis and dental caries. Experimental Studies in rats. Academic dissertation presented with the assent of the Faculty of Medicine, University of Oulu, for public discussion in auditorium 1 of the Institute of Dentistry (aapistie 3), 24 September 1999, at 12 noon. Institute of Dentistry, University of Oulu, Finland.

17. Kivela J, Parkkila S, Parkkila AK, Rajaniemi H (1999) A low concentration of carbonic anhydrase isoenzyme VI in whole saliva is associated with caries prevalence. Caries Res 33(3): 178-184.

18. Murray M, Wilson D (1942) Dental fluorosis and caries in London children. The Lancet 239 (6178): 98-99.

19. Rirattanapong P, Vongsavan K, Surarit R (2013) Effect of soft drinks on the release of calcium from enamel surfaces. Southeast Asian J Trop Med Public Health 44(5): 927-930.

20. Zhao W, Zhu H, Yu Z, Aoki K, Misumi J, Zhang X (1998) Long-term effects of Various Iodine and Fluorine Doses on the Thyroid and Fluorosis in Mice. Endocr Regul 32(2): 63-70. 


\section{Your next submission with Juniper Publishers will reach you the below assets}

- Quality Editorial service

- Swift Peer Review

- Reprints availability

- E-prints Service

- Manuscript Podcast for convenient understanding

- Global attainment for your research

- Manuscript accessibility in different formats

( Pdf, E-pub, Full Text, Audio)

- Unceasing customer service

Track the below URL for one-step submission https://juniperpublishers.com/online-submission.php 